\title{
The Analysis of Cohesive Devices Found in Good-Bye
}

\author{
Putu Sandra Putri Astariani \\ Linguistic, Master Programme \\ Faculty of Arts, Udayana University \\ Denpasar, Indonesia \\ Sandraputri.0808@gmail.com
}

\begin{abstract}
The basic definition of discourse is a language above sentences which is a cohesive, coherent, and functional. Cohesion and coherence are two vital elements constituting a discourse which are supported by the cohesive devices, i.e. reference, substitution, ellipsis, conjunctions, and lexical cohesion. This article discusses the cohesion and coherence of discourse through the identification of its cohesive devices. An anecdote entitled Good-Bye is selected due to its simplicity yet intriguing language, therefore the subliminal messages can be delivered and revealed. By using the qualitative approach and method, the results of the analysis, covering the cohesive devices within the text, can be comprehensively described. The analysis was carried based on the theory of functional grammar by MAK Halliday from his book Halliday's Introduction to Functional Grammar by MAK Halliday (revised by Christian MIM Matthiessen), about the cohesive devices. In addition to this one, the theory of cohesive devices from the book Cohesion in English by MAK Halliday and Ruqaiyah Hasan is used as a supporting theory. Within this anecdote, four out of five cohesive devices proposed by Halliday and Hasan were found. They covered the reference, ellipsis, conjunction, and lexical cohesion (reiteration and collocation). Unfortunately, substitution could not be found.
\end{abstract}

Keywords: Discourse, Cohesive Devices, Anecdotes, Cohesion, Coherence.

\section{INTRODUCTION}

There are countless definitions of the discourse given by experts; however, the most essential one is that discourse is language above sentence that is functional, cohesive, and coherent. Halliday and Hasan (1976, p.1) take text as "a unit of language in use" which can be "any passage, spoken or written, of whatever length, that does form a unified whole". While unlike Halliday and Hasan, Leech (in Wang and Guo, 2014:1) takes discourse as both written and spoken English. According to Halliday and Hasan (1976), two conditions must be fulfilled for a text to be coherent, i.e. a text must be consistent with the context in which it is created, the other is a text must have cohesion, which means all parts in a text must be connected by cohesive devices. In addition to Halliday and Hasan, van Dijk (1977) also shared his thought that coherence is a semantic property of discourse, based on the interpretation of each sentence relative to the interpretation of other sentences.
As has been previously mentioned, a coherent text must be cohesive which is connected by cohesive devices, which consists of reference, substitution, ellipsis, conjunctions, and lexical cohesion. The more frequent these devices are used in a text or a discourse, the more cohesive and coherent it will be.

In analyzing a discourse, accuracy, critical thinking, and good comprehension of its contents are required. These things are essential to give a deep explanation regarding what discourse is discussing and what messages are being or want to be delivered by the writer. The target or the object in discourse analysis is a unit of language above the sentence or utterance which has unity and context, can be a speech, manuscripts of recorded conversations, direct conversation, meeting notes, debates, lectures, or proselytizing religion and so forth (Purbani, 2005). They are not created on purpose and indeed portraying the real discourse in everyday life. As far as I am concerned, discourse analysis can also contribute to other disciplines since texts and 
discourses are the basic aspects of constructing any sciences.

One of the most popular discourses in public is a humorous or anecdotal discourse or anecdote. This article is trying to discover the cohesiveness of an anecdote through functional grammar and cohesion theory by applying the qualitative method. The theory, coined by MAK Halliday and Ruqaiyah Hassan, discuss a lot of things related to discourse. However, only one topic was taken to explain this issue in depth.

\section{MethodS AND PROCEDURES}

The data used is in the form of written discourse taken from a magazine entitled Inspirasi Vol. XIV No. 2 - July 2019 through the books.google.com page. This data is an anecdote (short humorous discourse or text). According to Kamus Besar Bahasa Indonesia (KBBI), an anecdote is cerita singkat yang menarik karena lucu dan mengesankan, biasanya mengenai orang penting atau terkenal berdasarkan kejadian yang sebenarnya (an interesting short story due to its funny and impressive content, it generally tells important or famous people based on actual events).

An anecdote is commonly sarcastic and almost similar to metaphor; showing important or wellknown figures who are close to everyday life; humorous, tickling, and contains a lot of jokes yet satirizes which is related to criticism purpose. An anecdote is chosen because of its simple language. Moreover, humorous discourse is more easily accepted by the community because of its light, nonwordy content, and similar situation as the society in general. In addition to what has been previously described, the most essential factor of choosing an anecdote for this research is the implied words and meaning. The subliminal messages lie within this text also becomes its challenges in analyzing this discourse.

Data were collected by using the documentation method supported note-taking technique. The documentation method focuses on language use either spoken or written. Sudaryanto ( 2015: 203) argues that this method is a way of obtaining data by paying attention to the use of language. The analysis was carried out descriptively by using a distributional method (metode agih). This means that the language is analyzed by using the determinants, in this case, the cohesive devices, found within it. To realize this method, the expansion technique is used (teknik perluasan) to analyze the unit of speech, besides this technique can be used to reveal the significance of a language.

Although this research aims at finding all cohesive devices in an anecdote, unfortunately not all of them can be found. The results of the analysis were presented in an informal method in which data are presented descriptively by using words without any presence of tables, equations, and numbers.

The theory used as the basis in analyzing the data is the theory of Cohesive Devices proposed by MAK Halliday and Ruqaiyah Hasan from their book Cohesion in English. To support this, the Functional Grammar theory obtained from a book entitled Halliday's Introduction to Functional Grammar by M.A.K. Halliday and was revised by Christian M.I.M. Matthiessen was used. This book mainly talks about all elements required in discourse analysis. However, to limit the discussion, only the section of Cohesive Devices was used as guidelines. The grand theory states that five elements determine the cohesiveness of a discourse, those are:

\subsection{Reference}

Halliday (2014) stated that "reference creates cohesion by creating links between elements", the point is reference connects a reference to the thing it refers to. Within a text or discourse, there are four types of frequently encountered reference, i.e. endophoric (if the elements associated with meaning are in the discourse) and exophoric (if the relationship occurs between the elements in the discourse with extralinguistic factors (elements outside the discourse), then endophoric can be divided into anaphoric (if an element refers to the previous element) and cataphoric (if an element in the discourse refers to the element afterward). Examples from each category are presented as follows:

\subsubsection{Endophoric}

Three blind mice, three blind mice. See how they run! See how they run!

(Halliday and Hasan, 1976: 31)

The word they endophorically refers to the word mice (located exactly within the discourse). This kind of reference tends to be easier to discover since the readers are not required to know the context of the situation within the discourse. The words are guiding them, instead.

\subsubsection{Exophoric}

For he's a good jolly fellow and so say all of us. (Halliday and Hasan, 1976: 32)

In this sentence, the reference he refers to an element outside the discourse. This element is unknown unless the context of the situation is recognized by reading and comprehending a whole discourse.

\subsubsection{Cataphoric}

One boy kicks the ball and it goes through the window and the ball breaks the window. (Halliday and Hasan, 1976: 35) 
Cataphorical reference is being portrayed here since the word it refers to the noun phrase the ball. This phrase is exactly located after the word it.

\subsubsection{Anaphoric}

Three boys are playing football and one boy kicks the ball and it goes through the window

(Halliday and Hasan, 1976: 35)

The word it is anaphorically referring to the noun phrase the ball, which exactly presents in the previous clause. In this sentence, there are three clauses separated by a conjunction and where the ball belongs to the second clause, while the word it follows the last clause.

\subsection{Substitution and Ellipsis}

Substitution and ellipsis are the cohesive devices after reference. Both may have similarities with references, but reference plays its role in the level of meaning (semantic level), while substitution and ellipsis significantly play a role in the level of phrases and clauses (syntactic level). Substitution is done to avoid repetition. While the notion of ellipsis carries the meaning of removal since it removes the elements of a sentence or discourse that has been mentioned previously. Ellipses can also be called zero substitution (replacement with empty elements). Both substitution and ellipsis can be divided into three types, namely: nouns, verbs, and clauses. Each instance is shown as follows:

\subsubsection{Nominal, Verbal, and Clause Substitution}

Nominal: "Jan loves to drink beer. He has one every day." One substitutes the word beer.

Verbal: "Jan loves to drink beer. He does every day." Does substitutes the verb phrase loves to drink

Clausal: "Does Jan love to drink beer?

I believe so [that he does, that he loves to drink beer]."

The word so substitutes the clause he loves to drink beer.

(Halliday and Hasan in Cohesion in English (1976)).

\subsubsection{Nominal, Verbal, and Clause Ellipsis \\ Nominal: "Would you like another beer?" \\ "Yes, another [beer] please."}

The word another is not necessarily followed by the word beer since it has been previously mentioned

Verbal: "Jan drank beer and Tomas [drank] slivovice"

The word drink is not required anymore since it has been mentioned in the previous clause.

Clausal: "Jan and his friends all had a beer this evening. Jan had his usual pilsner. Tomas had a summer ale and Marek [had a summer ale] too."
The clause had a summer ale is removed since it is the same as the previous one.

(Halliday and Hasan in Cohesion in English (1976) the explanation is excluded).

\subsection{Conjunction}

Halliday and Hasan in Cohesion in English stated that "Conjunctive elements are cohesive not in themselves but indirectly, under their specific meanings; they are not primarily devices for reaching out into the preceding (or following) text, but they express certain meanings which presuppose the presence of other components in the discourse." A conjunction can be defined as a phrase used to connect one element with the others, therefore readers can understand the connection of an idea with other ideas.

Conjunctions can be divided into three categories, namely Elaborating where one clause expands another by elaborating on it (or some portion of it): restating in other words, specifying in greater detail, commenting, or exemplifying; Extending which means one clause expands another by extending beyond it: adding some new element, giving an exception to it, or offering an alternative, and Enhancing where one clause expands another by embellishing around it: qualifying it with some circumstantial feature of time, place, cause or condition. (Halliday and Matthiessen, 2014: 444).

\subsection{Lexical Cohesion}

Lexical cohesion occurs due to the selection of certain words in the discourse. As stated by Halliday and Hasan (1976: 274) "This is the cohesive effect achieved by the selection of vocabulary". Lexical cohesion consists of reiteration and collocation. Reiteration is a repetition of a lexicon by using the same word, or more general terms, such as synonyms and superordinates. An example of reiteration is presented as follows:

- There was a large mushroom growing near her, about the same height as herself; and, when she had looked under it, it happened to her that she might as well look and see what was on the top of it. She stretched herself up on tiptoe, and peeped over the edge of the mushroom, ...

- Accordingly ... I took leave, and turned to the ascent of the peak. The climb is perfectly easy ...

- Henry is bought himself a new Jaguar. He practically lives in the car. (Halliday and Hasan, 1976: 278)

The first example portrays a reiteration by using the same word, namely mushroom in the sentence There was a large mushroom growing near her and the same word is repeated in the sentence peeped over the edge of the mushroom, .... the second example shows reiteration by using synonymy, i.e. climb and ascent. Meanwhile, the last example shows 
the use of superordinates, namely the word car is the superordinate of Jaguar.

Collocation is another aspect of lexical cohesion, meaning a combination of words in pair which cannot be replaced with another combination. In other words, it has a definite pair. Examples of collocations are heavy rain, instead of thick rain, and to look for a job, instead of to search for a job.

Furthermore, Halliday and Hasan also asserted that "any two lexical items have similar patterns of collation - that is, tending to appear in similar contexts will generate a cohesive force if they occur in adjacent sentences". This means that two collocated lexicon tends to appear in a similar context and will be cohesive when they appear in adjacent sentences, such as candle ... flame ... flicker and hair ... comb ... curl ... wave (Halliday and Hasan, 1976: 286).

\section{RESULTS}

The following data are presented as follows:

Sebuah keluarga sedang pergi ke Disney Land. Setelah melewati liburan yang menyenangkan dan melelahkan, mereka kembali ke rumah.

Saat mereka meninggalkan Disney Land, anak lakilaki melambaikan tangan dan berkata, "Goodbye, Mickey."

Lalu si anak perempuan juga melambaikan tangan dan berkata, "Goodbye, Minnie."

Kemudian si ayah juga melambaikan tangan dan dengan lemahnya berkata, "Goodbye, Money.”

\subsection{Reference}

Reference is found in the word mereka in the clause mereka kembali ke rumah and saat mereka meninggalkan disney land... refers to the word keluarga. This reference is anaphoric, since it refers to the previous element. This is strengthen by the fact that the word mereka cannot be determined without the presence of the word keluarga in the previous sentence.

\subsection{Substitution}

No substitution is found even though it should be presented within the discourse. In making anecdotes, substitution is often removed and the author tends to use repeated sentences to attract the reader's attention to know what will happen next. The following sentences are showing how the discourse would be if the substitution was used:
Saat mereka meninggalkan Disney Land, anak lakilaki melambaikan tangan dan berkata, "Goodbye, Mickey."

Lalu si anak perempuan juga melambaikan tangan dan berkata, "Goodbye, Minnie."

Kemudian si ayah juga melakukan hal yang sama dengan lemahnya berkata, "Goodbye, Money."

Substitution occurs by using the phrase melakukan hal yang sama to replace the phrase melambaikan tangan. This kind of substitution is classified as verbal substitution where the verb melambaikan tangan and replaced by melakukan hal yang sama.

\subsection{Ellipsis}

Sometimes it is very tricky to distinguish between substitution and ellipsis. However, this is portraying how ellipsis works within the text.

“...Setelah melewati liburan yang menyenangkan dan (liburan yang) melelahkan.”

The previous sentence consists of two clauses that are paratactically connected by conjunction dan, i.e. liburan yang menyenangkan and liburan yang melelahkan. The ellipsis occurs in the phrase liburan yang since it has been stated in the previous clause. Therefore, it will be ineffective to repeat the same thing, and as a result, repetition can be avoided. In addition to this phrase, another instance of ellipsis is also found in the following sentence.

“..., anak laki-laki melambaikan tangan dan (anak laki-laki) berkata...”

Two clauses are constructing this sentence, namely anak laki-laki melambaikan tangan and anak lakilaki berkata. These two clauses are parataxis in relationship connected by the same conjunction and. These clauses have the same phrases constructing them, namely anak laki-laki. As a result, ellipsis occurs in the second clause to avoid repetition.

“..., si anak perempuan juga melambaikan tangan dan (si anak perempuan juga) berkata...”

The next case of ellipsis is found in this sentence involving two clauses namely si anak perempuan juga melambaikan tangan and si anak perempuan juga berkata. Both of these clauses are connected with conjunction and are constructed by the same phrases, si anak perempuan. As a result, ellipsis occurs to create effective sentences and repetition.

“...si ayah juga melambaikan tangan dan (si ayah) dengan lemahnya berkata...” 
The sentence above consists of two clauses namely si ayah juga melambaikan tangan and (si ayah) dengan lemahnya berkata. These two clauses are paratactically connected with conjunctions and. Constructed by the same phrase, namely si ayah, ellipsis occurs on the second clause since the phrase si ayah has been clearly stated in the first clause.

\subsection{Conjunction}

The conjunctions found in this discourse are setelah, saat, lalu, kemudian, and dan. The analysis of each conjunction is explained as follows:

\subsubsection{Setelah (After)}

Conjunction setelah or after in English, links the clause melewati liburan yang menyenangkan dan melelahkan and the clause mereka kembali ke rumah, according to Halliday (2014) these clauses have a hypotactic relationship (unequal relationship). It belongs to the category of enhancing, to be more specific, it belongs to the category of simple-spatio temporal-enhancing which means a clause extends other clauses by "embellishing" these clauses, giving them features of time, place, cause, and condition. The data portrays that as conjunction, setelah shows the time feature when the family returns home.

\subsubsection{Dan (And)}

Conjunction dan (and) belongs to the category of extending, especially in positive-additive-extending where a clause expands another clause by adding new elements, providing exceptions to the clause and alternatives. There are several clauses connected by conjunction dan, i.e. ...anak laki-laki melambaikan tangan dan berkata...; Lalu si anak perempuan juga melambaikan tangan dan berkata, "Goodbye, Minnie."; ...si ayah juga melambaikan tangan dan dengan lemahnya berkata...; and setelah melewati liburan yang menyenangkan dan melelahkan. All of these sentences have a paratactic relationship/equal relationship since they are all constructed by an independent clause.

\subsubsection{Saat (When)}

Although Halliday and Matthiessen did not explain anything about this conjunction, when has a similar meaning to meanwhile. This is categorized as durative-spatio-temporal-enhancing since it extends other clauses by "embellishing" these clauses, giving them features of time, place, cause, and condition. The conjunction saat (when) links the clause mereka meninggalkan Disney Land with anak laki-laki melambaikan tangan dan berkata, "Goodbye, Mickey.". These clauses have a hypothetical or unequal relationship since it is constructed by one dependent and one independent clause. Therefore, the presence of a dependent clause is exactly required by the independent one. The conjunction saat is contributing to the category classification into enhancing, which means a clause extends another clause by "embellishing" the clause, giving it features of time, place, cause, and condition. The occurrence of saat indicates the time or period when the boy's activity was done.

\subsubsection{Lalu (Then)}

The sentence si anak perempuan juga melambaikan tangan dan berkata, "Goodbye, Minnie." is related to the previous sentence Saat mereka meninggalkan Disney Land, anak laki-laki melambaikan tangan dan berkata, "Goodbye, Mickey". Each of them is linked with the conjunction lalu (then) to express the sequence of events in order. This conjunction is categorized as enhancing, specifically in simple-spatio temporal-enhancing, where a clause extends another clause by "embellishing" the clause, giving it a feature of time, place, cause, and condition. In this sentence, the condition described is a continuation in which the girl also does the same thing as the boy in the family.

\subsubsection{Kemudian (Afterwards)}

Similar to lalu, kemudian also shows the sequence of events in order. This conjunction is used to connect the phrase ...si ayah juga melambaikan tangan dan dengan lemahnya berkata, "Goodbye, Money" with another sentence, Lalu si anak perempuan juga melambaikan tangan dan berkata, "Goodbye, Minnie.". Having the same category as the previous conjunction, namely simple-spatiotemporal-enhancing, this conjunction contributes to embellishing the clause connected with the feature of time and place, even in this context, situation. The sentence si ayah juga melambaikan tangan dan dengan lemahnya berkata, "Goodbye, Money" denotes a condition where the father regrets that he had spent too much money on family's holiday.

Based on the analysis, most of the conjunctions found are explicit conjunctions since they are explicitly shown or written within the discourse to link or connect the clauses. Thus the coherence and cohesion are fulfilled.

\subsection{Lexical Cohesion}

As the last element required to make a discourse both cohesive and coherent, lexical cohesion, unlike the other aspects, is broad. It does not have any clear patterns nor exact rules in determining this aspect. Lexical cohesion is divided into two, namely, reiteration and collocation. The type of reiteration 
found is repetition by using the same word or clause. This is indicated in the following sentence:

Saat mereka meninggalkan Disney Land, anak lakilaki melambaikan tangan dan berkata, "Goodbye, Mickey."

Lalu si anak perempuan juga melambaikan tangan dan berkata, "Goodbye, Minnie."

Kemudian si ayah juga melambaikan tangan dan dengan lemahnya berkata, "Goodbye, Money."

The phrase melambaikan tangan dan berkata is used three times within the discourse. Instead of using substitution, reiteration is chosen to attract the reader's enthusiasm toward the text.

In addition to reiteration, collocation is an interesting aspect found here. It is applied in the phrase melambaikan tangan (waving hand). Based on the Oxford Online Dictionary, to wave means a movement of your arm and hand from side to side. Thus logically, the action of waving is only conducted by using hands, not leg nor head. Therefore, the word melambaikan/waving can only occur with the word tangan/hand(s) making them into a fixed pair of words or collocation.

\section{CONCLUSIONS}

Based on the analysis, for a discourse to be cohesive and coherent, having cohesive devices is a must. The anecdote portrays how almost all of the cohesive devices are effectively used, thus the meaning and the purpose are well-delivered to the readers. In Good-Bye, there are four out of five cohesive devices found, namely reference, ellipsis, conjunction, and lexical cohesion. Unfortunately, there is no indication of substitution is used. Based on the theory of cohesive devices proposed by Halliday and Hasan in Cohesion in English (1976) and Halliday and Mathiessen in Introduction to Functional Grammar (2014), all of the devices were analyzed in depth. Although substitution is missing, it can be used, yet due to the nature of anecdote that tends to repeat words to attract the attention of the reader, then substitution is not used. This study is expected to have implications and contributions to both theory and the learning process of the Indonesian language through a discourse, therefore, any suggestions and advice are welcome for the sake of the development of this article.

\section{REFERENCES}

[1] Halliday MAK and Christian MIM Matthiessen. (ed.). 2014. Halliday's Introductions to Functional Grammar. Routledge, United Kingdom.
[2] Halliday, MAK and Ruqaiyah Hasan. 1976. Cohesion in English. Hong Kong: Sheck Wah Tong Printing Press.

[3] https://corpora.unileipzig.de/en/res?corpusId=en g_news_2016\&word=bath (accessed on November 26, 2019)

[4] https://elt-resourceful.com/tag/ellipsis-andsubstitution/ (accessed 26 November 2019)

[5] https://kbbi.web.id/ (accessed 26 November 2019)

[6] http://staffnew.uny.ac.id/upload/131874171/pen gabdian/discourse-analysis.pdf (accessed 26 November 2019)

[7] Inspiration Magazine Vol. XIV July 2, 2019

[8] Karadeniz, Abdulkerim. 2017. Cohesion and Coherence in Written Texts of Students of Faculty of Education. Journal of Education and Training StudiesVol. 5, No.2 February 2017 (https://files.eric.ed.gov/fulltext/EJ1125748.pdf)

[9] Kridalaksana, Harimurti. 2008. Kamus Linguistik. Jakarta: Pt. Gramedia Pustaka Utama.

[10] https://www.oxfordlearnersdictionaries.com/ (accessed 26 November 2019)

[11] Wang, Yuan and Minghe Guo. 2014. A Short Analysis of Discourse Coherence. Journal of Language Teaching and Research, Vol. 5, No. 2, pp. 460-465 (http://www.academypublication.com/issues/past /jltr/vol05/02/27.pdf) 